\title{
Spectral Patterns Reveal Early Resistance Reactions of Barley Against Blumeria graminis f. sp. hordei
}

\author{
Matheus Thomas Kuska, ${ }^{\dagger}$ Anna Brugger, Stefan Thomas, Mirwaes Wahabzada, Kristian Kersting, Erich-Christian Oerke, \\ Ulrike Steiner, and Anne-Katrin Mahlein
}

First, second, third, fourth, sixth, seventh, and eighth authors: Institute for Crop Science and Resource Conservation (INRES)-Phytomedicine, University of Bonn, Nussallee 9, 53115 Bonn, Germany; fifth author: CS Department and Centre for Cognitive Science, TU Darmstadt, Hochschulstrasse 1, 64289 Darmstadt, Germany; and eighth author: Institute of Sugar Beet Research (IfZ), Holtenser Landstraße 77, 37079 Göttingen, Germany.

Accepted for publication 28 June 2017.

\begin{abstract}
Differences in early plant-pathogen interactions are mainly characterized by using destructive methods. Optical sensors are advanced techniques for phenotyping host-pathogen interactions on different scales and for detecting subtle plant resistance responses against pathogens. A microscope with a hyperspectral camera was used to study interactions between Blumeria graminis f. sp. hordei and barley (Hordeum vulgare) genotypes with high susceptibility or resistance due to hypersensitive response (HR) and papilla formation. Qualitative and quantitative assessment of pathogen development was used to explain changes in hyperspectral signatures. Within $48 \mathrm{~h}$ after inoculation, genotype-specific changes in the green and red range (500 to $690 \mathrm{~nm}$ ) and a blue shift of the red-edge inflection point

were observed. Manual analysis indicated resistance-specific reflectance patterns from 1 to 3 days after inoculation. These changes could be linked to host plant modifications depending on individual host-pathogen interactions. Retrospective analysis of hyperspectral images revealed spectral characteristics of HR against $B$. graminis f. sp. hordei. For early HR detection, an advanced data mining approach localized HR spots before they became visible on the RGB images derived from hyperspectral imaging. The link among processes during pathogenesis and host resistance to changes in hyperspectral signatures provide evidence that sensor-based phenotyping is suitable to advance time-consuming and cost-expensive visual rating of plant disease resistances.
\end{abstract}

Physical and chemical barriers such as waxy cuticle, cell wall, and constitutive antimicrobial compounds are the first defense of plants against fungal pathogens (Dangl and Jones 2001). Even when a potential pathogen overcomes these preformed defense mechanisms, the pathogen is confronted with the inducible immune system (Jones and Dangl 2006). Two resistance mechanisms of Hordeum vulgare against Blumeria graminis $\mathrm{f}$. sp. hordei, the causal agent of barley powdery mildew, are based on different processes and are operative at different stages of pathogenesis. Dysfunction of the $H$. vulgare mildew locus o ( mlo) gene triggers the formation of effective cell wall appositions (papillae) at sites of B. graminis f. sp. hordei penetration sites during the first approximately $40 \mathrm{~h}$ after inoculation (hai) and inhibit penetration (Jørgensen 1992; Röpenack et al. 1998). This papilla formation is based on fast and high local accumulations of callose, arabinoxylan, polysaccharides, ferulic acid, and cellulose (Chowdhury et al. 2014). Plasmamembrane-associated callose synthases are transported in vesiclelike bodies to $B$. graminis $\mathrm{f}$. sp. hordei penetration sites after conidia get in contact with the leaf (Bayles et al. 1990; Eggert et al. 2014). The following deposition of $(1,3)$ - $\beta$-glucan polymers and callose synthesis establishes a polymer network between the plasma membrane and the cellulosic cell wall, which acts as a penetration barrier (Bayles et al. 1990; Chowdhury et al. 2014, Eggert et al. 2014; Skou 1985).

$H$. vulgare lines and cultivars with a $B$. graminis $\mathrm{f}$. $\mathrm{sp}$. horde $i$ racespecific resistance mildew locus a $(M l a)$ gene are characterized by a fast, single-cell hypersensitive response (HR) to B. graminis f. sp. hordei penetration (Hückelhoven et al. 1999). The H. vulgare Mla

†Corresponding author. E-mail: mkuska@uni-bonn.de

*The $\boldsymbol{e}$-Xtra logo stands for "electronic extra" and indicates that one supplementary table and four supplementary figures are published online.

(C) 2017 The American Phytopathological Society locus encodes a high number of leucine-rich repeat proteins for different B. graminis f. sp. hordei isolate-specific resistances (Seeholzer et al. 2010). Mla resistance is activated by avirulence locus a effectors from $B$. graminis f. sp. hordei during leaf penetration (Bieri et al. 2004), which lead to an WRKYl-based signal cascade (Chang et al. 2013). Finally, the penetrated cell undergoes a programmed cell death (Hückelhoven and Kogel 1998).

The identification and characterization of processes during plant resistance reactions against fungal pathogens are essential for plant breeding to select new resistant genotypes. In breeding practice, phenotyping of genotypes is realized by time-consuming, subjective, and expensive visual plant ratings. Noninvasive sensors could improve and accelerate plant phenotyping in breeding for disease resistance (Chaerle et al. 2004; Fiorani and Schurr 2013; Mahlein 2016). Hyperspectral imaging (HSI) has shown the potential to determine different plant parameters and to identify plant diseases (Mahlein et al. 2012; Simko et al. 2017; Wahabzada et al. 2016). Recently, there have been a few examples suggesting that plant resistance reactions influence the spectral properties of plants (Arens et al. 2016; Iori et al. 2015; Kuska et al. 2015; Leucker et al. 2016, 2017; Oerke et al. 2016).

The aforementioned resistance reactions of $H$. vulgare against $B$. graminis f. sp. hordei change the leaf physiology and require several chemical compounds, which can have specific optical properties. Papillae produce an autofluorescence, resulting from the accumulation of cell-wall-bound phenolic compounds (Röpenack et al. 1998). The local cell death induced by HR is a regulated complex process with multiple compounds involved in different types of cell collapse (Greenberg 1997), which include pigment degradation (e.g., of chlorophyll [Chl]) (Matile and Hörtensteiner 1999). Changes in the Chl content and photosynthetic activity as well as further leaf compounds can be measured noninvasively using hyperspectral reflectance (Curran 1989; Gay et al. 2008; Gitelson et al. 2003; Yendrek et al. 2017).

The present study identified specific hyperspectral reflectance patterns in the visual (VIS, 400 to $700 \mathrm{~nm}$ ) and near infrared (NIR, 
700 to $1000 \mathrm{~nm}$ ) range of HR- and papillae- based resistance by elucidating optical properties of different types of plant-pathogen interactions. Linking reflectance spectra to histological observations revealed events and relevant time points in pathogenesis.

\section{MATERIALS AND METHODS}

Plant material and cultivation. $H$. vulgare 'Ingrid' wild type (WT) and the corresponding near-isogenic line Ingrid M. C. 20, containing resistant mildew locus o 3 (mlo3) (Hinze et al. 1991), as well as H. vulgare 'Pallas 01', containing resistant mildew locus a 1 and a 12 (Mlal and Mla12, respectively), were used (Boyd et al. 1995; Kølster et al. 1986). Experimental plants were grown in commercial substrate (Klasmann-Deilmann $\mathrm{GmbH}$ ) for 10 days in the greenhouse at 23 and $20^{\circ} \mathrm{C}$ and a photoperiod of $16 \mathrm{~h}$. The primary leaves were then transferred on phyto agar plates containing $0.34 \mathrm{mM}$ benzimidazole.

Pathogen and inoculation. B. graminis f. sp. horde $i$ isolate K1 (Hacquard et al. 2013) was used to analyze the mlo3 and Mlal resistance response (Shen et al. 2003; Zhou et al. 2001). Preliminary investigations showed that Mla12 is not effective in this interaction (Shen et al. 2003). B. graminis f. sp. hordei K1 was maintained on $H$. vulgare 'Tocada' in a controlled environment. At $24 \mathrm{~h}$ before plant inoculation, the conidia of heavily infested plants were shaken off and discarded to ensure homogenous and vital conidia for inoculation. Detached leaves on phyto agar were inoculated with a density of $\bar{X}=329( \pm 107)$ conidia/ $\mathrm{cm}^{2}$ from a young powdery mildew pustule ( 7 to 10 days after inoculation [dai]) using an aseptic brush. For each barley genotype, four leaves were inoculated with B. graminis f. sp. hordei and four leaves were kept noninfected as control. The agar plates were sealed with Parafilm M (Bemis) and incubated in a growth chamber at $19^{\circ} \mathrm{C}$, illuminance of 1,100 $\mathrm{cd} \mathrm{m}^{-2}$, and a photoperiod of $16 \mathrm{~h} /$ day.

Histological observation and quantification. For histological analysis of B. graminis f. sp. hordei development on different genotypes, further plant sets were prepared in parallel. Leaf discs harvested daily from 0 until 4 dai were fixed for $15 \mathrm{~h}$ at approximately $23^{\circ} \mathrm{C}$ in an ethanol-chloroform $(75: 25$ [vol/vol]) mixture containing $0.15 \%$ trichloroacetic acid (Wolf and Fric 1981). Probes were stained in a dye solution of $1: 1$ volume of $15 \%$ trichloroacetic acid and 0.6\% Coomassie brilliant blue R-250 (dissolved in 99\% methanol) for $12 \mathrm{~min}$ before microscopic analysis. Total amounts of conidia as well as conidia which were able to germinate to form appressoria to develop a penetration peg and to develop mycelium were quantified daily until 4 dai.

$\mathrm{H}_{2} \mathrm{O}_{2}$ generation was investigated by an endogenous peroxidasedependent staining in 3,3'-diaminobenzidine (DAB) $(1 \mathrm{mg} / \mathrm{ml})$ for $15 \mathrm{~h}$ at approximately $23^{\circ} \mathrm{C}$ (Thordal-Christensen et al. 1997). DAB polymerizes instantly and locally as soon as it comes into contact with $\mathrm{H}_{2} \mathrm{O}_{2}$ and then has a brownish color. Epidermal cells and mesophyll cells as well as anticline cell walls stained by polymerized DAB were quantified daily until 4 dai. Specimens were examined under a Leica DMR 6000B photomicroscope (Leica).

HSI and manual data extraction. A previously described hyperspectral microscope (Kuska et al. 2015) was used for time series imaging. Hyperspectral images were acquired with a line scanner (ImSpector PFD V10E; Spectral Imaging Ltd.) with a spectral range of 400 to $1,000 \mathrm{~nm}$ and a spectral resolution of $2.73 \mathrm{~nm}$. Hyperspectral measurements were performed in the dark. Magnification was adjusted to $\times 7.3$ (spatial resolution approximately $7.5 \mu \mathrm{m} / \mathrm{pixel}$ ). Spectral binning and spatial binning were set to 1 . Frame rate and exposure time were adjusted to the object. A detailed description of the measuring setup is provided by Kuska et al. (2015).

Hyperspectral data cubes were acquired daily until 8 dai. To receive the relative reflectance, a white reference bar (SphereOptics $\mathrm{GmbH})$ was recorded $(\mathrm{W})$, followed by a dark current image $\left(\mathrm{B}_{1}\right)$. Subsequently, the leaf sample $\left(\mathrm{I}_{0}\right)$ and a corresponding dark current image $\left(\mathrm{B}_{2}\right)$ were recorded. Calculation of relative reflectance was according to the formula $\mathrm{I}=\left(\mathrm{I}_{0}-\mathrm{B}_{2}\right) /\left(\mathrm{W}-\mathrm{B}_{1}\right)$, using the software ENVI 5.1 + IDL 8.3 (ITT Visual Information Solutions). The resulting spectral signals were smoothed by employing the Savitzky-Golay filter (Savitzky and Golay 1964) and cut below $420 \mathrm{~nm}$ and above $830 \mathrm{~nm}$, because of data noise. Parameters for the smoothing process were 25 supporting points and a thirddegree polynomial.

Spectral signatures of pixels from healthy and diseased regions were extracted manually and retrospectively from the last experimental day (Fig. 1). Depending on the development of symptomatic areas, an ellipsoid region of interest of approximately 300 to 127,000 (WT), 300 to 70,000 (mlo3), and 880 to 5,100 (Mlal) pixels was extracted per day and specimen. This retrospective signature extraction was used to determine individual interaction spots accurately over the experimental period, because symptoms and resistance responses were visible on the last day of the experiment. For mlo genotypes, the region of interest in the leaf center was chosen on empirical values based on preexperiments with the hyperspectral microscope. The extracted reflectance was averaged for ellipsoid areas of interest. These were used to calculate the arithmetic average as well as the standard deviation between the biological replicates. Differences in hyperspectral reflectance among genotypes and over time were calculated according to Carter and Knapp (2001). To enable significant thresholds for spectral differences, a variance propagation with a level of significance of $90 \%$ was applied by calculating $\left\{\left(\left[\left(\sigma_{\text {healthy }} / 2\right)^{\wedge} 2\right]+\left[\left(\sigma_{\text {inoculated }} / 2\right)^{\wedge} 2\right]\right)^{\wedge}(1 / 2)\right\} \times 1.64$ for every wavelength. Afterward, the arithmetic mean of the variance propagation was calculated from every wavelength per genotype and days after inoculation. The mean variance propagation per genotype and days after inoculation were subsequently averaged and used as the threshold of significance.

Automated data mining of spectral dynamics by HR. A data mining approach following Kuska et al. (2015) was adapted to efficiently analyze the incompatible barley Mlal-B. graminis f. sp. hordei system (Fig. 1). Simplex volume maximization (SiVM), which establishes a fast archetypal analysis, was introduced (Thurau et al. 2012). It computes a low-dimensional representation where each hyperspectral signature is represented by a convex combination of only a few extreme signatures. The resulting coefficients are proportions adding up to 1 and describing the relative contribution of each of the extremes to a hyperspectral signature. The columns in the coefficient matrix can be considered as data points from a simplex spanned by the extreme basis vectors. This allows for a statistical analysis at a massive scale (Wahabzada et al. 2015a). Using this region, the signatures that characterize the specific measurements for the resistance reactions could be automatically extracted.

To determine cells undergoing an HR, the method was further modified by using preclustering, which compiles similar signatures of all measured leaves per day and considers the groups of signatures instead of single observations in further processing. In addition, it also captured the spectral differences of diseased leaves. Overall, the approach consists of the following steps. First, it employs SiVM to determine a few extremes from hyperspectral images of all leaves and time points. Then, it represents all signatures as a combination of selected extremes. Third, measurements of all leaves per day were clustered using the new representation, where each data point is considered a sample from the simplex, spanned by the extremes (Leucker et al. 2017; Wahabzada et al. 2015b). Finally, for each cluster, a simplex distribution such as Dirichlet was computed using the coefficients obtained by SiVM. In terms of the Bhattacharyya distance (Kailath 1967), clusters with the highest differences to the distributions of healthy leaves were chosen for further consideration.

In this experiment, the number of extremes computed by $\mathrm{SiVM}$ was set to $k=25$ and the number of clusters to $c=16$. Three clusters with the highest differences in terms of Bhattacharyya distance were selected. It should be noted that, prior to computing the factorization, the signatures were normalized by their Euclidean norm to mitigate the effects of varying reflectance intensities due to specular or uneven surface. 


\section{RESULTS}

Microscopic analysis of the interaction phenotypes. The B. graminis f. sp. hordei ontogenesis on leaves of susceptible Ingrid WT barley was in accordance with the typical asexual lifecycle described, which includes prepenetration stages (conidia germination, development of functional appressoria, and penetration pegs) and postpenetration stages (fully developed haustoria, epiphytic mycelium, and conidiophores). The transition from prepenetration to postpenetration stage started approximately 10 hai, indicated by

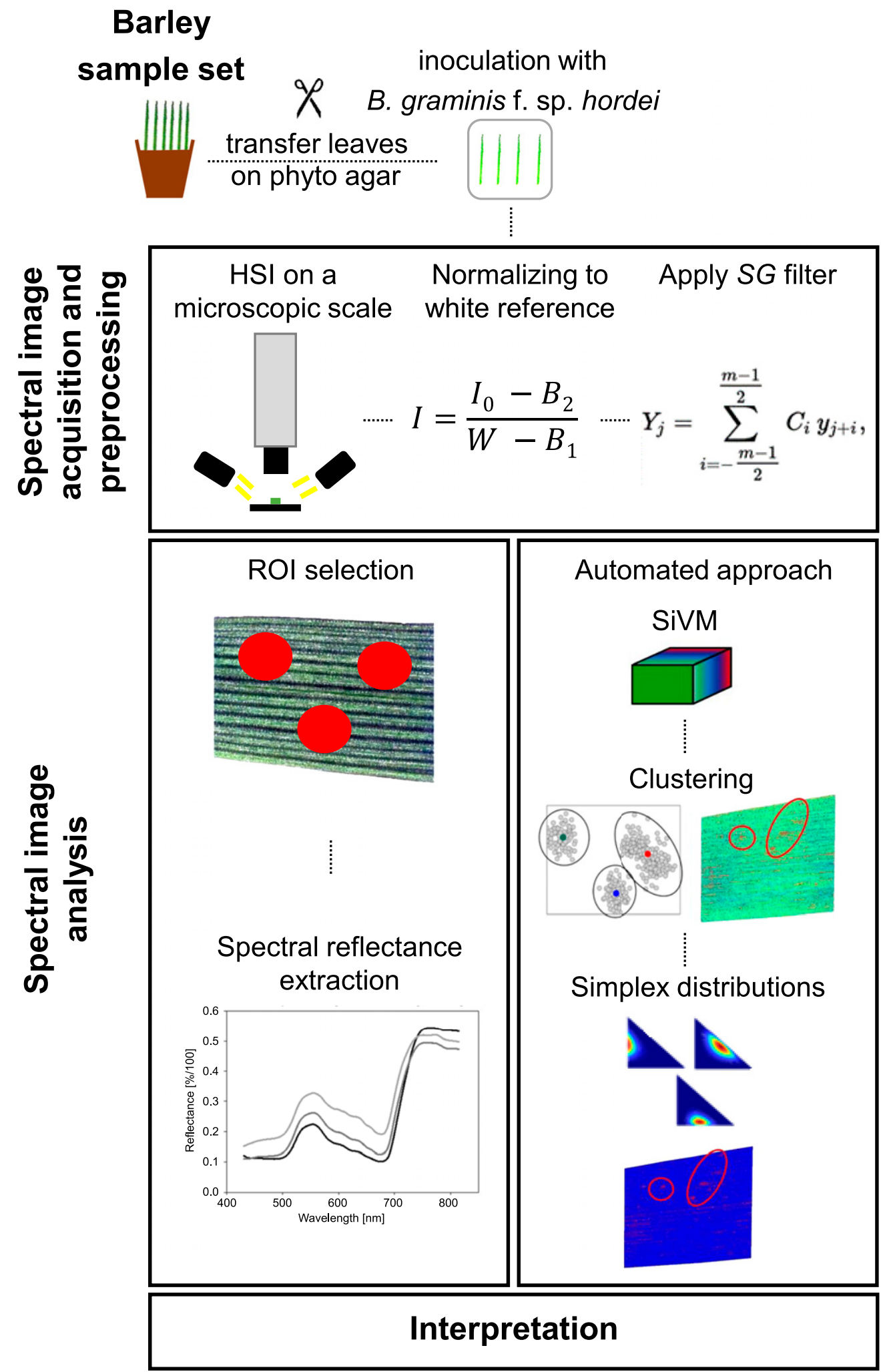

Fig. 1. Detection and analysis of plant-pathogen interactions using hyperspectral imaging (HSI). Primary leaves of young barley plants were transferred on phyto agar and inoculated with Blumeria graminis f. sp. hordei using an aseptic brush. After hyperspectral image acquisition and normalization, the Savitzky-Golay filter was applied to reduce data noise. Reflectance values were manually and retrospectively extracted from regions of interest. For the automated detection of hypersensitive response spots (HR maps), simplex volume maximization (SiVM) was applied to compute a low-dimensional representation of all hyperspectral signatures per image and pixel. Hyperspectral images were clustered using the new representation. For each cluster, a simplex distribution was computed. Finally, spectral signatures and HR maps were displayed and interpreted. 
fully developed appressoria (Fig. 2) and the first functional haustoria (approximately 24 hai) (Supplementary Fig. S1). Epiphytic hyphae were formed 2 dai, and increased in number and length during the next days. First conidiophores with conidia appeared 4 dai. Powdery mildew pustules were visible to the human eye 4 dai (Supplementary Fig. S2).

On Mlal and mlo3 resistant leaves, the B. graminis f. sp. hordei conidia successfully developed primary and secondary germ tubes as well as appressoria (Fig. 2). Epidermal cells with functional haustoria were not present on inoculated mlo3 leaves, even though approximately $75 \%$ conidia were germinated. The $B$. graminis $\mathrm{f}$. sp. hordei development stopped on the epidermal cell wall and conidia were shriveled on mlo3 leaves 4 dai. On Mlal resistant leaves, approximately $1 \%$ of the conidia penetrated epidermal cells and successfully formed haustoria 3 dai. Further development stopped and the asexual life cycle could not be completed by the pathogen.

Generation of $\mathrm{H}_{2} \mathrm{O}_{2}$ was observed as an indicator for barley reactions related to HR response and papilla development (Fig. 3).
Susceptible WT leaves generated $\mathrm{H}_{2} \mathrm{O}_{2}$ in approximately 20 epidermal cells $/ \mathrm{cm}^{2} 1$ dai (Fig. 3). Epidermal cells with haustoria did not show $\mathrm{H}_{2} \mathrm{O}_{2}$ generation 2 dai (Fig. 3).

In mlo3 resistant leaves, $\mathrm{H}_{2} \mathrm{O}_{2}$ was generated around the $B$. graminis f. $\mathrm{sp}$. hordei penetration site 1 to 2 dai, indicating the role of $\mathrm{H}_{2} \mathrm{O}_{2}$ in papilla formation. $\mathrm{H}_{2} \mathrm{O}_{2}$ generation decreased in these leaves 3 and 4 dai and was observed mainly in the anticline cell walls.

Mlal resistant leaves showed $\mathrm{H}_{2} \mathrm{O}_{2}$ generation in approximately 26 epidermal cells $/ \mathrm{cm}^{2} 1$ dai, which increased to approximately 45 epidermal cells $/ \mathrm{cm}^{2} 4$ dai (Fig. 3). In addition, $\mathrm{H}_{2} \mathrm{O}_{2}$ generation was detected in the anticline walls of epidermal cells (Fig. 3). Mesophyll cells generating $\mathrm{H}_{2} \mathrm{O}_{2}$ were detected only in Mlal leaves 4 dai. $\mathrm{H}_{2} \mathrm{O}_{2}$ generation in Mlal leaves increased in epidermal and mesophyll cells until 5 to 6 dai (Supplementary Fig. S3). These became macroscopically visible as necrotic spots between 5 and 7 dai. The cellular quantification of $\mathrm{H}_{2} \mathrm{O}_{2}$ indicated three $H$. vulgare-B. graminis $\mathrm{f}$. sp. hordei interaction phenotypes.

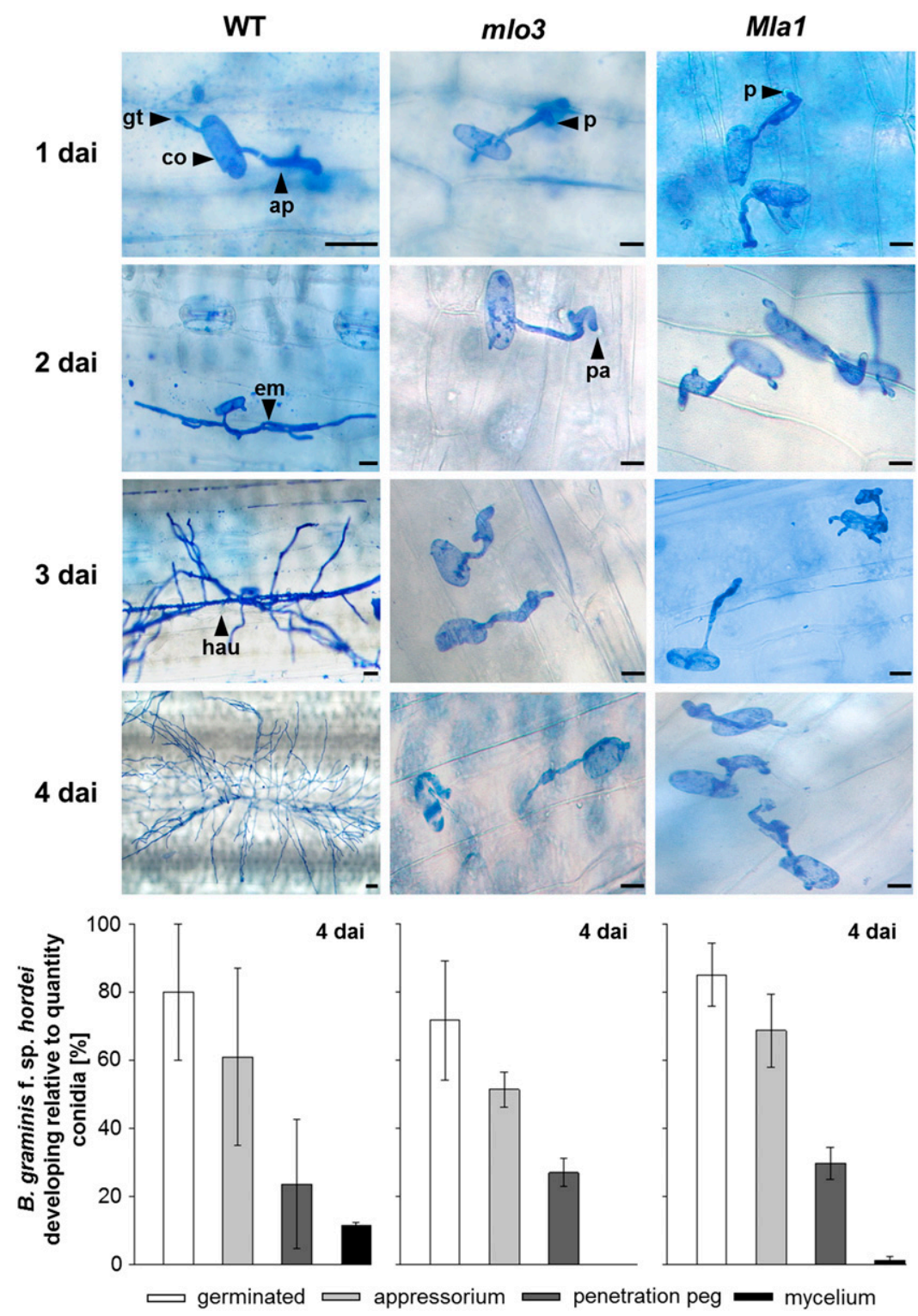

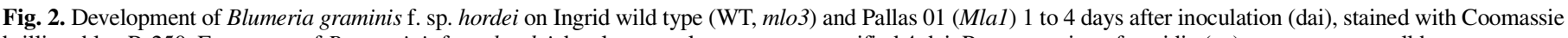

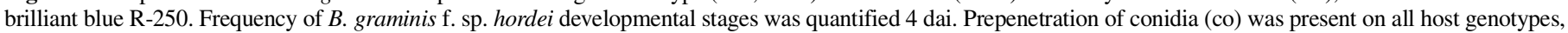

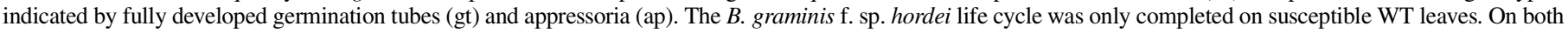

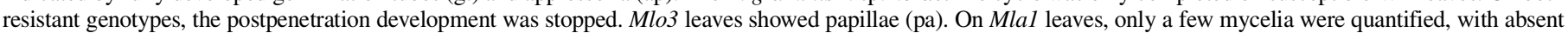

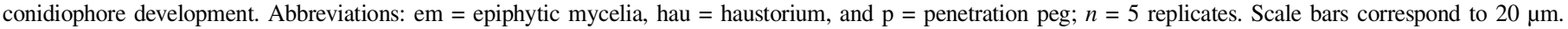
Quantitative mean of inoculated conidia per square centimeter: WT $=223$, mlo3 $=406$, and Mlal $=330$; error bars indicate relative standard deviation. 
Hyperspectral signatures of powdery mildew, HR, and papilla. Hyperspectral reflection changed over time specifically for each genotype during disease progression (Fig. 4). Spectral differences were calculated between reflectance of healthy and B. graminis f. sp. hordei-inoculated leaves to consider effects of the host genotype and the influence of leaf senescence (Fig. 5).

After inoculation, all genotypes showed similar reflectance in the VIS (400 to $700 \mathrm{~nm}$ ) and NIR (700 to $830 \mathrm{~nm}$ ) range, without significant spectral differences to the corresponding noninoculated leaves (Fig. 4). First spectral changes appeared 2 dai on Mlal resistant leaves in reflectance from 400 to 690 and 720 to $830 \mathrm{~nm}$. Differences spectra indicated significant differences around approximately 680 and from 720 to $830 \mathrm{~nm}$ (Fig. 5). Reflectance from 400 to 480,510 to 580, and 610 to $690 \mathrm{~nm}$ increased gradually 3 dai (Fig. 4C). Spectral difference were also visible in the NIR range; here, inoculated Mlal resistant leaves showed the lowest reflectance intensity among all three genotypes (Fig. 5). Noninoculated WT leaves had a decreased reflectance at 500 to $660 \mathrm{~nm}$ and at approximately $710 \mathrm{~nm}$. Later, these leaves had an increased reflectance at 400 to $680 \mathrm{~nm}$, in the red edge, and a slightly decreased reflectance in the NIR 7 dai (Fig. 4D). The spectral reflectance of inoculated mlo3 resistant leaves increased from 480 to $670 \mathrm{~nm} 2$ dai (Fig. 4B). This phenomenon changed to the opposite from 3 dai (Fig. 5).

Important spectral changes during barley-powdery mildew interactions are summarized in Table 1 .

Automatic detection of HR on Mlal leaves against $B$. graminis f. sp. hordei. In order to assess the influence of the HR of Mlal resistance, changes in spectral characteristics of inoculated Mlal leaves that showed necrotic spots 8 dai were analyzed over time (Fig. 6). The hyperspectral signature of HR spots had an increased reflectance 8 dai. Reflectance was increased in the range from green to red and caused a blue shift in the red inflection point (Fig. 6). This dynamic reflectance pattern had high similarity with the mean reflectance of inoculated Mlal leaves (Supplementary Fig. S4). Necrotic spots on Mlal leaves appeared 5 to 6 dai. For earlier detection of these necrotic spots corresponding to HR regions, an unsupervised clustering approach was adapted. Binary

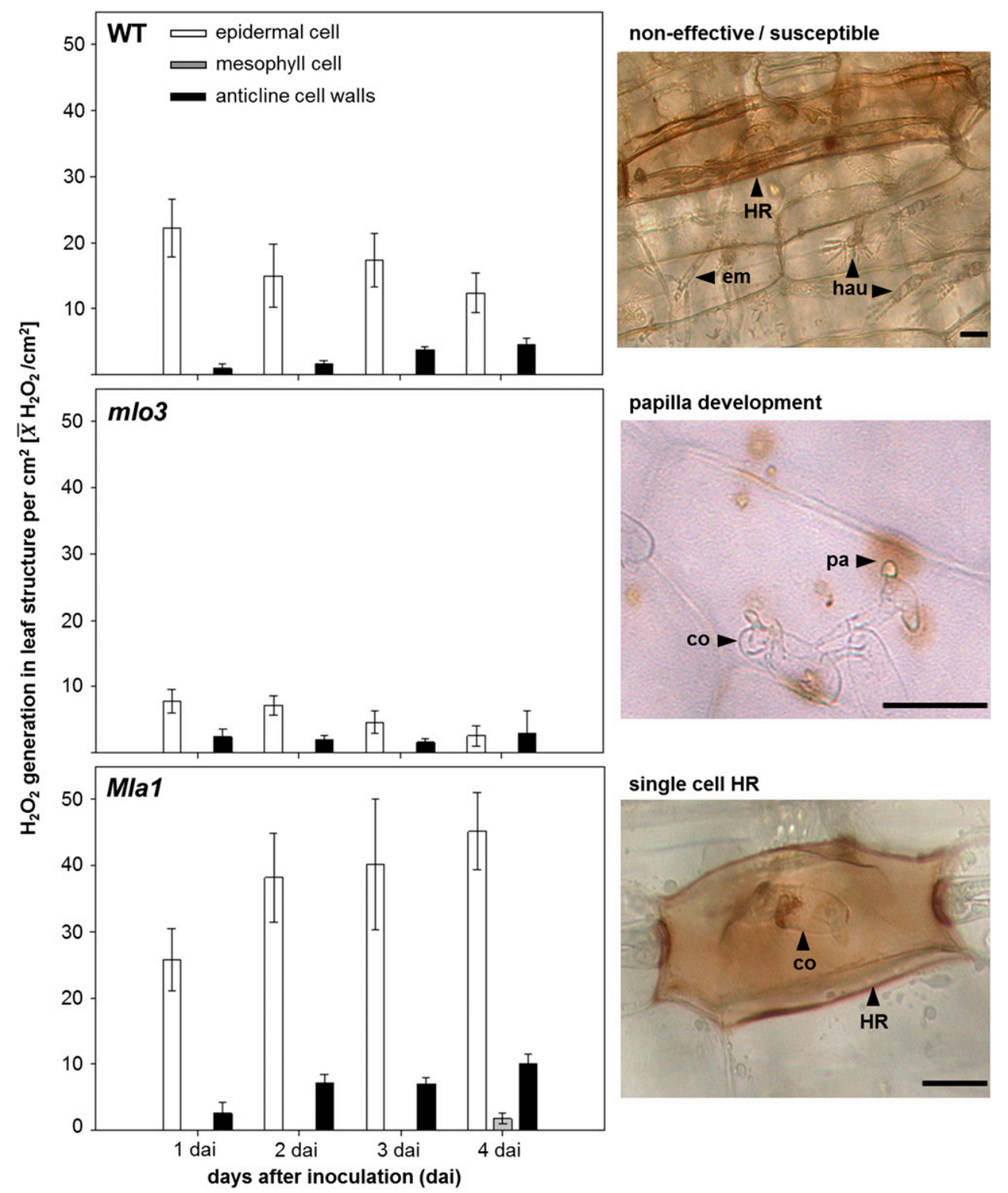

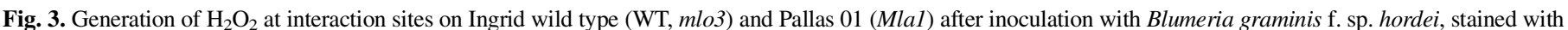

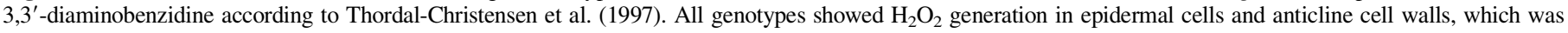

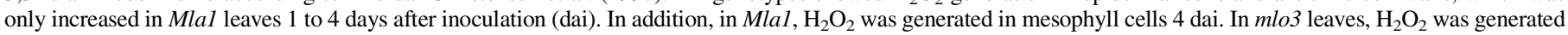

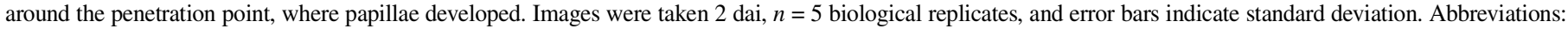

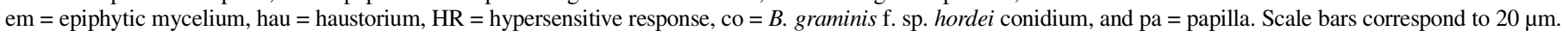




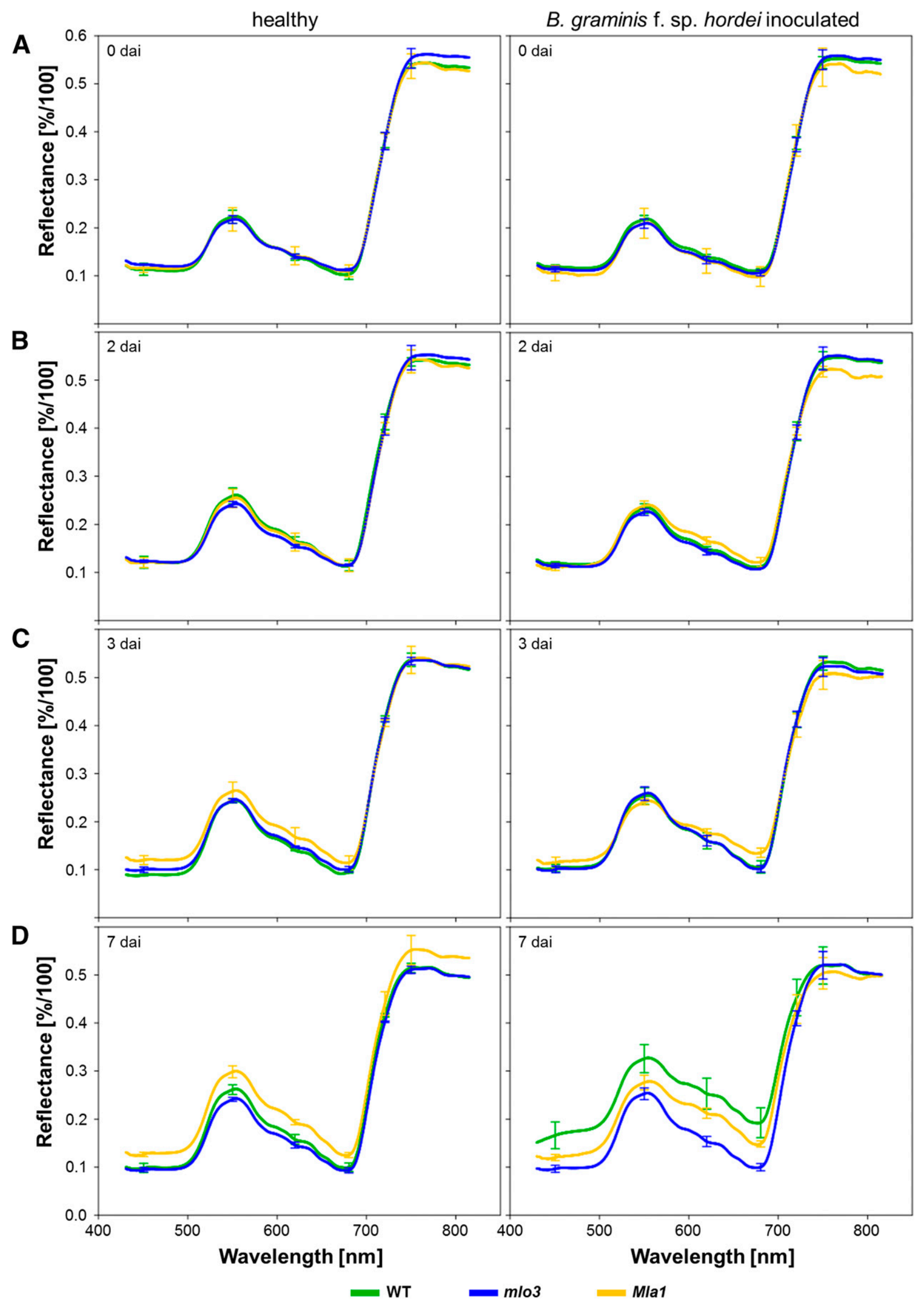

Fig. 4. Spectral signatures of healthy Hordeum vulgare leaves and inoculated with Blumeria graminis f. sp. hordei, Ingrid (WT, mlo3) and Pallas 01 (Mla1) A, 0; B, 2; C, 3; and $\mathbf{D}, 7$ days after inoculation (dai). Reflectance spectra of inoculated genotypes were similar at 0 dai, without significant differences from the corresponding spectrum of the healthy leaf. Mlal reflectance intensity increased in the green range (approximately $680 \mathrm{~nm}$ ) and decreased in the near infrared 2 dai (B). These changes became more prominent 3 dai (C). Susceptible WT leaves showed increased reflectance over the entire spectrum 7 dai. In total, $n=4 \times(\geq 300)$ biological replicates $\times$ technical replicates, and relative standard deviation per near-isogenic line over time and measured wavelength range was 0.8 to 20,1 to 8,1 to 13 , and 2 to $17 \%$ (A to $\mathrm{D}$, respectively). 
maps from hyperspectral data visualized pixels, indicating healthy leaf tissue in black and HR spots in yellow (Fig. 7). On corresponding pseudo RGB images, HR spots were visible for the first time 5 dai. These HR spots were absent on earlier days. Binary maps already indicate HR spots at 2 dai.

\section{DISCUSSION}

Powdery mildew pathogenesis-related processes influence the VIS-NIR spectrum of barley. Typical B. graminis f. sp. hordei pathogenesis on detached WT leaves was associated with

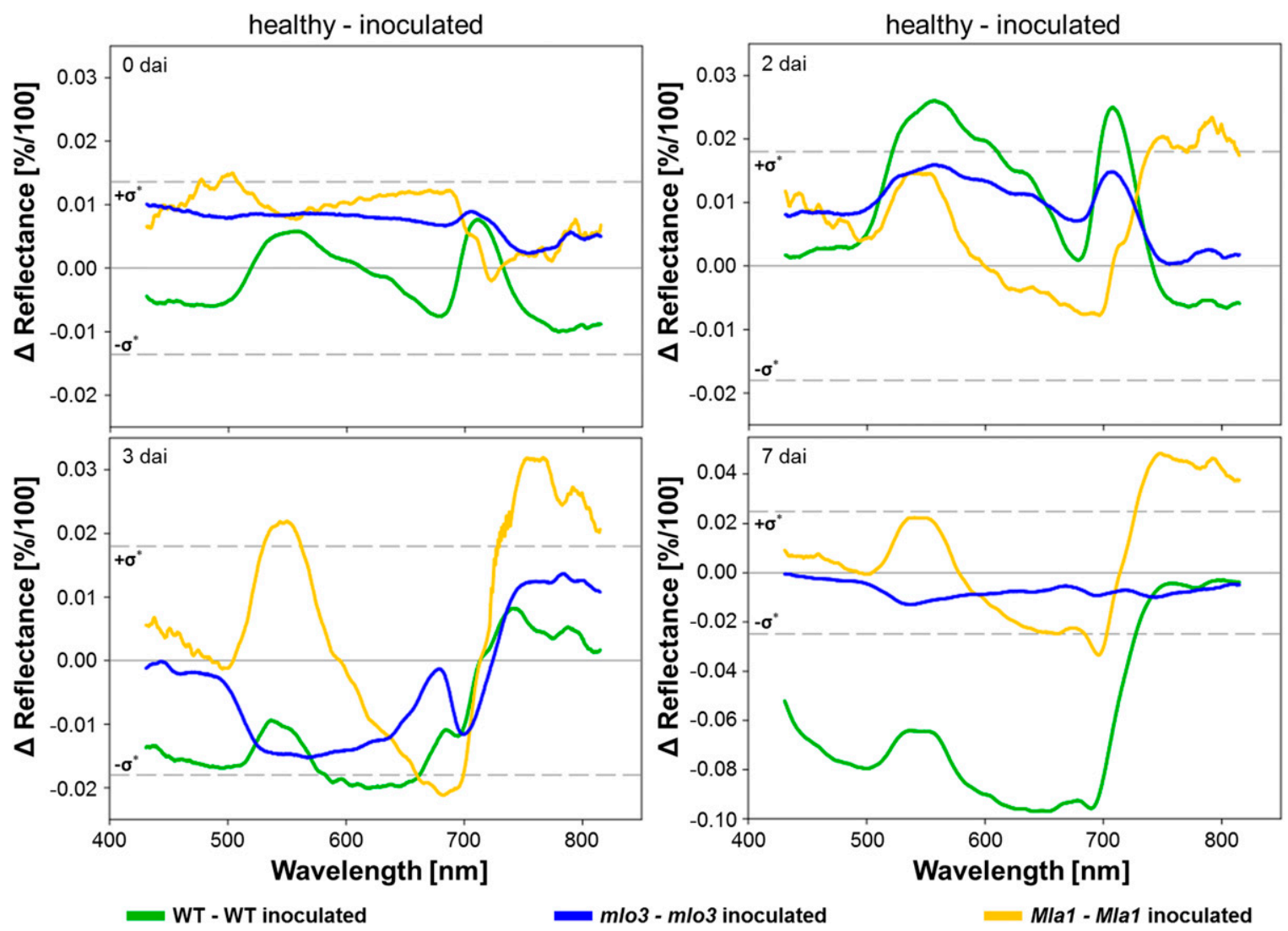

Fig. 5. Differences in the spectral reflectance of healthy and Blumeria graminis f. sp. hordei-inoculated Hordeum vulgare leaves, Ingrid (WT, mlo3), and Pallas 01 (Mla1) 0, 2, 3, and 7 days after inoculation (dai). Positive values in the difference plot demonstrate higher reflectance intensity of healthy leaves and negative values higher reflectance intensity of inoculated leaves. The highest measure of dispersion over the whole difference spectrum of all barley genotypes per day after inoculation is indicated by $\pm \sigma^{*}$ and is used as the threshold of significance. Measure of dispersion were calculated as a variance propagation with a $90 \%$ level of significance $(n=4 \times(\geq 300)$ biological replicates $\times$ technical replicates $)$.

TABLE 1. Influence of individual interaction types of barley near-isogenic lines on spectral reflectance during powdery mildew infestation, papilla formation and hypersensitive response ${ }^{\mathrm{a}}$

\begin{tabular}{lll}
\hline Interaction type, interaction time frame & Relevant functional spectral range & Description \\
\hline Powdery mildew (wild type) & & Decelerated senescence \\
Early & $500-660 \mathrm{~nm}$ & Structural and physiological changes \\
Established, nonvisible & $400-680 \mathrm{~nm}$ & Structural and physiological changes \\
& Approximately $690 \mathrm{~nm}$ & Structural and physiological changes \\
Late & Approximately $710 \mathrm{~nm}$ & Collapsing and chlorotic tissue \\
Papilla formation (mlo3) & $400-730 \mathrm{~nm}$ & \\
Early & & Decelerated senescence \\
Formation & $400-690 \mathrm{~nm}$ & Decelerated senescence \\
& Approximately $700 \mathrm{~nm}$ & Putative cell wall apposition \\
Established & $480-670 \mathrm{~nm}$ & Putative cell wall apposition \\
Hypersensitive response $($ Mlal) & Approximately $700 \mathrm{~nm}$ & Putative cell wall apposition \\
Early & $730-830 \mathrm{~nm}$ & $\ldots$ \\
Established & $\ldots$ & Structural and physiological changes \\
& & Structural and physiological changes \\
Late & $600-680 \mathrm{~nm}$ & Necrotized single cells \\
& $720-830 \mathrm{~nm}$ & Necrotized single cells \\
\end{tabular}

${ }^{a}$ Relevant spectral ranges were selected on the basis of spectral differences between healthy and inoculated genotypes. Relevant wavelength ranges with the highest significance are indicated. 
dynamics in hyperspectral reflectance of susceptible barley leaves and whole plants (Kuska et al. 2015; Thomas et al. 2016; Wahabzada et al. 2015a). The first spectral differences between healthy and $B$. graminis f. sp. hordei-inoculated WT leaves appeared 2 dai at approximately 500 to 650 and $710 \mathrm{~nm}$, when primary haustoria and first epiphytical mycelium developed. These spectral differences indicate a temporary inhibited senescence of inoculated WT leaves. This phenomenon may be initiated by $B$. graminis f. sp. hordei inhibiting the senescence which is linked to pathogenesis-related gene expressions (Robatzek and Somssich 2002). Senescence is described as a resistance mechanism against biotrophic fungal pathogens, which the invader tries to impede (Häffner et al. 2015). After haustorium development, effector proteins are secreted by $B$. graminis f. sp. hordei to successfully infest the plant and to overcome plant immunity (Ahmed et al. 2015; Robatzek and Somssich 2001, 2002). Nevertheless, the reflectance of the inoculated WT increased in the VIS range from 3 dai. This reflectance increase was due to the pathogen overgrowing the leaf surface with dense mycelia and conidiophores, where new conidia were produced
(Kuska et al. 2015; Thomas et al. 2017; Wahabzada et al. 2015a). This optical effect was also visible at approximately $710 \mathrm{~nm}$, which is correlated to structural parameters and resulting scattering processes (Green et al. 2002; Thomas et al. 2017; Wahabzada et al. 2015a). Later stages of powdery mildew pustules showed increased reflectance from 560 to $700 \mathrm{~nm}$, which corresponds to chlorotic plant tissue (Kuska et al. 2015). This spectral pattern is linked to the reduction of Chl content and a reduced rate of photosynthesis during powdery mildew infestation (Scholes et al. 1994; Swarbrick et al. 2006).

Mla resistance uncovered by HSI. The Mla trigger is necessary to start a transcriptional reprogramming of the infested cell (Blanvillain et al. 2011; Hückelhoven et al. 2000). The programmed cell death induces a collapsing of the infested cell, which also involves the reduction of plant pigments (Matile and Hörtensteiner 1999). Increased reflectance from 600 to $700 \mathrm{~nm}$ indicated a reduction of the photosynthetic activity already at 2 dai in inoculated Mlal leaves, which became significant from 3 dai. Several investigations could not confirm the supposed reduction of chloroplasts during cell death (Van Aken and Breusegem 2015). This is in accordance with lower
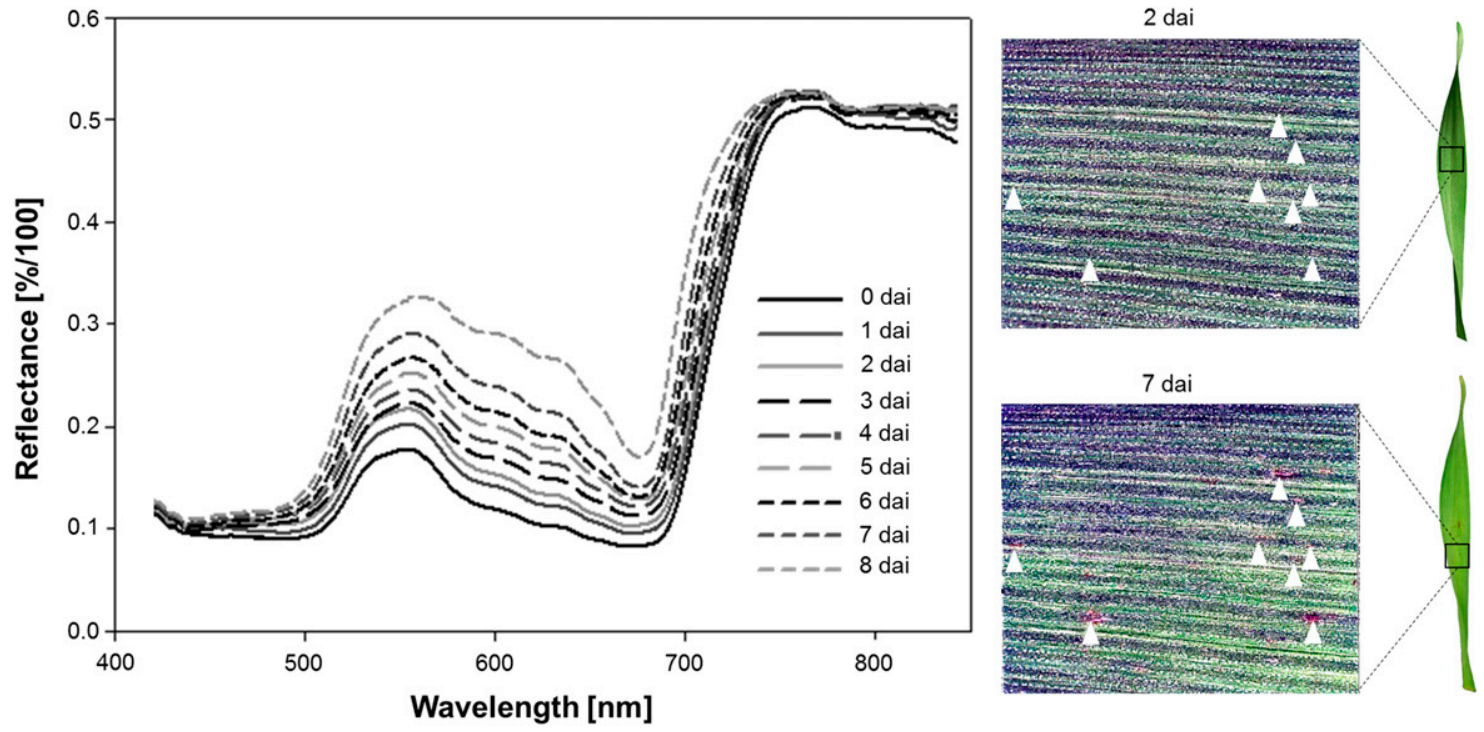

Fig. 6. Spectral characteristics of hypersensitive response (HR) spots on near-isogenic Hordeum vulgare Pallas 01 (Mlal) 0 to 8 days after inoculation (dai) and the corresponding hyperspectral and RGB (taken with a Canon digital camera [EOS 6 D]) images 2 and 7 dai. Spectral properties of HR were manually extracted and spots were monitored retrospectively. The first HR sites became visible to the human eye 5 to 8 dai. The reflectance pattern changed over time by increased intensity in the blue and green range (approximately $680 \mathrm{~nm}$ ) and a blue shift in the red edge.

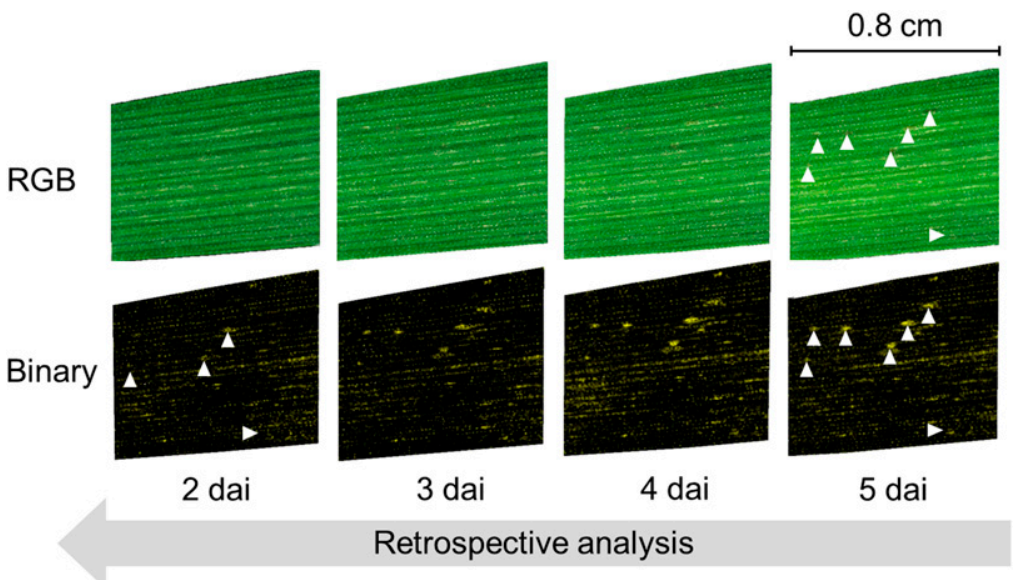

Fig. 7. Automatically determined hypersensitive response (HR) spots of near-isogenic line Hordeum vulgare Pallas 01 (Mlal) 2 to 5 days after inoculation (dai) by retrospective analysis. Black pixels indicate healthy leaf tissue and accumulated light pixels indicate HR spots. Detected HR spots matched with brownish HR spots on the RGB images from hyperspectral measurements 5 dai. These HR spots were also detected at earlier time points on the binary maps, which were not visible on the corresponding RGB image. 
reflectance in the green peak of inoculated Mlal leaves from 2 dai. In addition, studies by Melis and Harvey (1981) showed that the photosynthesis rate can be different from the $\mathrm{Chl}$ content, due to the chloroplast ultrastructure. However, structural changes indicate a decreased reflectance of Mlal leaves in the NIR. This corresponds to collapsing cells during HR. At time points of spectral changes, collapsing cells could be observed microscopically by increased $\mathrm{H}_{2} \mathrm{O}_{2}$ generation in inoculated Mlal leaves 1 to 4 dai. This $\mathrm{H}_{2} \mathrm{O}_{2}$ generation takes place before the cell death (Hückelhoven et al. 1999; Thordal-Christensen et al. 1997). Local necrotized tissue in inoculated Mlal leaves also showed $\mathrm{H}_{2} \mathrm{O}_{2}$ generation beneath the mesophyll tissue. This is in accordance with mildew loci study by Kogel and Hückelhoven (1999), who observed superoxide generation in mesophyll cells as well as necrotic mesophyll tissue in the incompatible Mla12 (HR) barley-powdery mildew system. The necrotized tissue in Mlal leaves were spectrally indicated in decreased reflectance of the NIR 7 dai.

The influences on spectral signatures in the VIS-NIR by HR could be transferred to other host-pathogen systems. This could be hypothesized because the oxidative burst by an HR induced cell death with a complex but organized cell collapse (Baxter et al. 2014; Greenberg and Yao 2004).

Formation of mlo3 papilla transiently influence spectral signature. During mlo3-mediated cell-wall appositions, a complex of lignin, cellulose, callose, arabinoxylan, ferulic acid peroxidases, phenols, proteins, and diverse cell-wall materials are accumulated (Chowdhury et al. 2014). Studies of foliar chemistry of healthy plants and spectral properties from remote sensing demonstrated correlations of compounds such as lignin, cellulose, callose, and proteins to spectral reflectance of plants (Curran 1989; Gates et al. 1965). Papilla formation presumes local and early reflectance changes in the blue range and NIR. The first significant changes occurred with an increased reflectance from 490 to $660 \mathrm{~nm}$ and approximately $710 \mathrm{~nm}$ at 2 dai. This spectral pattern was transient and returned to normal within a few days. Temporal processes during papilla formation are indicated by cytoplasmic streaming in attacked epidermal cells (Bushnell and Bergquist 1975). This aggregation was 10 to $30 \mu \mathrm{m}$ in diameter and the remaining functional papilla approximately 10 to $15 \mu \mathrm{m}$ only (Bushnell and Bergquist 1975). The hyperspectral microscope used has a spectral resolution of $7.5 \mu \mathrm{m} / \mathrm{pixel}$, which translates in 1.4 to 12.3 pixels for the aggregation and 1.4 to 3.2 pixels for the remaining papilla (Supplementary Table $\mathrm{S} 1$ ). An epidermal cell is approximately 15 times larger and is imaged at 67 to 125 pixels; by this, a higher influence of early stages on spectral signatures can be assumed. These cytoplasmic streams are filled with several compounds (e.g., vesicles and proteins) relevant for plant defense responses, especially during papilla aggregations (Freytag et al. 1994; Kobayashi et al. 1997; Schmelzer 2002). After papilla formation, the nuclei of the epidermal cells are repositioned and cytoplasmic streaming is reduced to normal levels (Bushnell and Bergquist 1975; Schmelzer 2002). This is in accordance with the transient increase of spectral reflectance of inoculated mlo3 leaves 2 dai, which is not detectable on later days because the resistance response has been completed and is restricted to a tiny portion of the leaf surface compared with HR of total cells in Mla-mediated resistance.

Objective and accurate resistance phenotyping by HSI. Visual assessment and symptom quantification has a variable error rate and is strongly influenced by the human rater (Nutter et al. 1993, 2006). To overcome these unfavorable circumstances on different levels, a large number of highly sensitive sensors and multiple data analysis approaches have been investigated (Bock et al. 2010, Großkinsky et al. 2015; Mahlein 2016; Simko et al. 2017).

To date, early detection and assessment of plant-pathogen interaction types was only realized by destructive analysis. The microscopic phenotyping system "HyphArea" by Seiffert and Schweizer (2005) allows an objective quantification of B. graminis f. sp. hordei hyphal growth rate 30 hai. In addition, the detection of
Mla9 (HR) resistance was established between 50 and 54 hai by the invasive HyphArea system. In a previous HSI study, an HSI analysis pipeline already allowed early detection of $B$. graminis f. sp. hordei infestation at 3 dai (Kuska et al. 2015). The HSI microscope enabled monitoring of the development of the same individual (e.g., pustule or HR) over time. HR maps indicated noninvasively all HR spots 2 to 3 dai, which could be visible by the human eye on RGB images 5 to 6 dai. In addition to reduced labor intensity, HSI enabled the determination of different $H$. vulgareB. graminis f. sp. hordei interactions. Susceptible and resistant HR or papilla genotypes can be distinguished 2 to 3 dai using the HSI data. In a next step, these results will be evaluated on different scales to analyze the scalability of spectral patterns of resistance response. In future research, the assessed spectral range will be increased to the shortwave infrared range to analyze physiological parameters and changes (e.g., in proteins, cellulose, sugars, and fatty acids) based on hyperspectral images (Curran 1989).

The approach presented here can expand studies such as the determination of Arabidopsis thaliana mutant phenotypes in powdery mildew interactions by molecular methods and histological quantifications (Weßling and Panstruga 2012). Recently, reactions of grapevine genotypes with different resistances to Plasmopara viticola were characterized by using HSI (Oerke et al. 2016). HSI also showed promising results in investigating two quantitative trait loci of sugar beet resistance against Cercospora leaf spot using the same hyperspectral microscope (Leucker et al. 2017). New insights for a biological interpretation of spectral signatures enable the development of spectral models characterizing specific plant-pathogen interactions. Therefore, correlations between subtle biochemical and physiological processes with hyperspectral signatures must be investigated. Furthermore, identification of scale-independent traits is required to utilize new insights across different scales, from the lab to the field. These studies can be enhanced using additional sensors to analyze different physiological parameters and link them to HSI (e.g., Chl fluorescence) (Pan et al. 2015; Zhao et al. 2016). This will improve common and state-of-the-art technologies in plant sciences and will enable fast and accurate plant resistance screening.

\section{ACKNOWLEDGMENTS}

This work could be carried out due to the financial support of the German Federal Ministry of Education and Research (BMBF) within the scope of the competitive grants program "Networks of excellence in agricultural and nutrition research-CROP.SENSe.net" (funding code: 0315529), junior research group "Hyperspectral phenotyping of resistance reactions of barley", and the Daimler and Benz foundation. We thank S. Tüffers and M. Namini for supporting microscopic investigations and J. Behmann for statistical advices.

\section{LITERATURE CITED}

Ahmed, A. A., Pedersen, C., Schultz-Larsen, T., Kwaaitaal, M., Jørgensen, H. J. L., and Thordal-Christensen, H. 2015. The barley powdery mildew candidate secreted effector protein CSEP0105 inhibits the chaperone activity of small heat shock protein. Plant Physiol. 168:321-333.

Arens, N., Backhaus, A., Döll, S., Fischer, S., Seiffert, U., and Mock, H. P. 2016. Non-invasive presymptomatic detection of Cercospora beticola infection and identification of early metabolic responses in sugar beet. Front. Plant Sci. 7:1377.

Baxter, A., Mittler, R., and Suzuki, N. 2014. ROS as key players in plant stress signalling. J. Exp. Bot. 65:1229-1240.

Bayles, C. J., Ghemawat, M. S., and Aist, J. R. 1990. Inhibition by 2-deoxy-Dglucose of callose formation, papilla deposition, and resistance to powdery mildew in an ml-o barley mutant. Physiol. Mol. Plant Pathol. 36:63-72.

Bieri, S., Mauch, S., Shen, Q. H., Peart, J., Devoto, A., Casais, C., Ceron, F., Schulze, S., Steinbiß, H. H., Shirasi, K., and Schulze-Lefert, P. 2004. Rar1 positively controls steady state levels of barley Mla resistance proteins and enables sufficient Mla6 accumulation for effective resistance. Plant Cell 16: 3480-3495. 
Blanvillain, R., Young, B., Cai, Y. M., Hecht, V., Varoquaux, F., Delorme, V., Lancelin, J. M., Delseny, M., and Gallois, P. 2011. The Arabidopsis peptide kiss of death is an inducer of programmed cell death. EMBO J. 30:1173-1183.

Bock, C. H., Poole, G. H., Parker, P. E., and Gottwald, T. R. 2010. Plant disease severity estimated visually, by digital photography and image analysis, and by hyperspectral imaging. Crit. Rev. Plant Sci. 29:59-107.

Boyd, L. A., Smith, P. H., Foster, E. M., and Brown, J. K. M. 1995. The effects of allelic variation at the Mla resistance locus in barley on the early development of Erysiphe graminis f. sp. hordei and host response. Plant J. 7:959-968.

Bushnell, W. R., and Bergquist, S. E. 1975. Aggregation of host cytoplasm and the formation of papillae and haustoria in powdery mildew of barley. Phytopathology 65:310-318.

Carter, G. A., and Knapp, A. K. 2001. Leaf optical properties in higher plants: Linking spectral characteristics to stress and chlorophyll concentrations. Am. J. Bot. 88:677-684

Chaerle, L., Hagenbeek, D., De Bruyne, E., Valcke, R., and Van Der Straeten, D. 2004. Thermal and chlorophyll-fluorescence imaging distinguish plantpathogen interactions at an early stage. Plant Cell Physiol. 45:887-896.

Chang, C., Deshui, Y., Jiao, J., Jing, S., Schulze-Lefert, P., and Shen, Q. H. 2013. Barley Mla immune receptors directly interfere with antagonistically acting transcription factors to initiate disease resistance signalling. Plant Cell Physiol. 25:1158-1173.

Chowdhury, J., Henderson, M., Schweizer, P., Burton, R. A., Fincher, G. B., and Little, A. 2014. Differential accumulation of callose, arabinoxylan and cellulose in nonpenetrated versus penetrated papillae on leaves of barley infected with Blumeria graminis f. sp. hordei. New Phytol. 204:650-660.

Curran, P. J. 1989. Remote sensing of foliar chemistry. Remote Sens. Environ. 30:271-278

Dangl, J. L., and Jones, J. D. G. 2001. Plant pathogens and integrated defence response to infection. Nature 411:826-833.

Eggert, D., Naumann, M., Reimer, R., and Voigt, C. A. 2014. Nanoscale glucan polymer network causes pathogen resistance. Sci. Rep. 4: Article 4159. doi: 10.1038/srep04159

Fiorani, F., and Schurr, U. 2013. Future scenarios for plant phenotyping. Annu. Rev. Plant Biol. 64:267-291.

Freytag, S., Arabatzis, N., Hahlbrock, K., and Schmelzer, E. 1994. Reversible cytoplasmic rearrangements precede wall apposition, hypersensitive cell death and defense-related gene activation in potato/Phytophthora infestans interactions. Planta 194:123-135.

Gates, D. M., Keegan, H. J., Schelter, J. C., and Weidner, V. R. 1965. Spectral properties of plants. Appl. Opt. 4:11-20.

Gay, A., Thomas, H., Roca, M., James, C., Taylor, J., Rowland, J., and Ougham, H. 2008. Nondestructive analysis of senescence in mesophyll cells by spectral resolution of protein synthesis-dependent pigment metabolism. New Phytol. 179:663-674

Gitelson, A., Gritz, Y., and Merzlyak, M. N. 2003. Relationships between leaf chlorophyll content and spectral reflectance and algorithms for non-destructive chlorophyll assessment in higher plant leaves. J. Plant Physiol. 160:271-282.

Green, J. R., Carver, T. L. W., and Gurr, S. J. 2002. The formation and function of infection and feeding structures. Pages 66-82 in: The Powdery Mildews-A Comprehensive Treatise. R. R. Bélanger, W. R. Bushnell, A. J. Dik, and T. L. W. Carver, eds. The American Phytopathological Society Press, St. Paul, MN.

Greenberg, J. T. 1997. Programmed cell death in plant-pathogen interactions. Annu. Rev. Plant Physiol. Plant Mol. Biol. 48:525-545.

Greenberg, J. T., and Yao, N. 2004. The role and regulation of programmed cell death in plant-pathogen interactions. Cell. Microbiol. 6:201-211.

Großkinsky, D. K., Svensgaar, J., Christensen, S., and Roitsch, T. 2015. Plant phenomics and the need for physiological phenotyping across scales to narrow the genotype-to-phenotype knowledge gap. J. Exp. Bot. 66: 5429-5440.

Hacquard, S., Kracher, B., Maekawa, T., Vernaldi, S., Schulze-Lefert, P., and Themaat, E. V. L. 2013. Mosaic genome structure of the barley powdery mildew pathogen and conservation of transcriptional programs in divergent hosts. Proc. Natl. Acad. Sci. USA 110:E2219-E2228.

Häffner, E., Konietzki, S., and Diederichsen, E. 2015. Keeping control: The role of senescence and development in plant pathogenesis and defense. Plants 4:449-488.

Hinze, K., Thompson, R. D., Ritter, E., Salamini, F., and Schulze-Lefert, P. 1991. Restriction fragment length polymorphism-mediated targeting of the ml-o resistance locus barley (Hordeum vulgare). Proc. Natl. Acad. Sci. USA 88:3691-3695.

Hückelhoven, R., Fodor, J., Preis, C., and Kogel, K. H. 1999. Hypersensitive cell death and papilla formation in barley attacked by the powdery mildew fungus are associated with hydrogen peroxide but not with salicylic acid accumulation. Plant Physiol. 119:1251-1260.

Hückelhoven, R., Fodor, J., Trujillo, M., and Kogel, K. H. 2000. Barley Mla and Rar mutants compromised in the hypersensitive cell death response against Blumeria graminis f. sp. hordei are modified in their ability to accumulate reactive oxygen intermediates at sites of fungal invasion. Planta 212:16-24

Hückelhoven, R., and Kogel, K. H. 1998. Tissue-specific superoxide generation at interaction sites in resistant and susceptible near-isogenic barley lines attacked by the powdery mildew fungus (Erysiphe graminis $\mathrm{f}$. $\mathrm{sp}$. hordei). Mol. Plant-Microbe Interact. 11:292-300.

Iori, A., Scala, V., Cesar, D., Pinzari, F., D’Egidio, M. G., Fanelli, C., Fabbri, A. A., Reverberi, M., and Serranti, S. 2015. Hyperspectral and molecular analysis of Stagonospora nodorum blotch disease in durum wheat. Eur. J. Plant Pathol. 141:689-702.

Jones, J. D. G., and Dangl, J. L. 2006. The plant immune system. Natl. Rev. 444:323-329.

Jørgensen, J. H. 1992. Discovery, characterization and exploitation of Mlo powdery mildew resistance in barley. Euphytica 63:141-152.

Kailath, T. 1967. The divergence and bhattacharyya distance measures in signal selection. IEEE Trans. Commun. 15:52-60.

Kobayashi, Y., Kobayashi, I., Funaki, Y., Fujimoto, S., Takemoto, T., and Kunoh, H. 1997. Dynamic reorganization of microfilaments and microtubules is necessary for the expression of non-host resistance in barley coleoptile cells. Plant J. 11:525-537.

Kogel, K. H., and Hückelhoven, R. 1999. Superoxid generation in chemically activated resistance of barley in response to inoculation with powdery mildew fungus. J. Phytopathol. 147:1-4.

Kølster, P., Munk, L., Stølen, O., and Løhde, J. 1986. Near-isogenic barley lines with genes for resistance to powdery mildew. Crop Sci. 26:903-907.

Kuska, M., Wahabzada, M., Leucker, M., Dehne, H. W., Kersting, K., Oerke, E. C., Steiner, U., and Mahlein, A. K. 2015. Hyperspectral phenotyping on the microscopic scale: Towards automated characterization of plantpathogen interactions. Plant Methods 11:28.

Leucker, M., Mahlein, A. K., Steiner, U., and Oerke, E. C. 2016. Improvement of lesion phenotyping in Cercospora beticola-sugar beet interaction by hyperspectral imaging. Phytopathology 106:177-184.

Leucker, M., Wahabzada, M., Kersting, K., Peter, M., Beyer, W., Steiner, U., Mahlein, A. K., and Oerke, E. C. 2017. Hyperspectral imaging reveals the effect of sugar beet quantitative trait loci on Cercospora leaf spot resistance. Funct. Plant Biol. 2:177-184.

Mahlein, A. K. 2016. Plant disease detection by imaging sensors-Parallels and specific demands for precision agriculture and plant phenotyping. Plant Dis. 100:241-251.

Mahlein, A. K., Steiner, U., Hillnhütter, C., Dehne, H. W., and Oerke, E. C. 2012. Hyperspectral imaging for small-scale analysis of symptoms caused by different sugar beet disease. Plant Methods 8:3.

Matile, P., and Hörtensteiner, S. 1999. Chlorophyll degradation. Annu. Rev. Plant Physiol. Plant Mol. Biol. 50:67-95.

Melis, A., and Harvey, G. W. 1981. Regulation of photosystem stoichiometry, chlorophyll a and chlorophyll b content and relation to chloroplast ultrastructure. Biochim. Biophys. Acta 637:138-145.

Nutter, F. W., Esker, P. D., and Netto, R. A. C. 2006. Disease assessment concepts and the advancements made in improving the accuracy and precision of plant disease data. Eur. J. Plant Pathol. 115:95-103.

Nutter, F. W., Gleason, M. L., Jenco, J. H., and Christians, N. C. 1993. Assessing the accuracy, intra-rater repeatability, and inter-rater reliability of disease assessment systems. Phytopathology 83:806-812.

Oerke, E. C., Herzog, K., and Toepfer, R. 2016. Hyperspectral phenotyping of the reaction of grapevine genotypes to Plasmopara viticola. J. Exp. Bot. 67: 5529-5543.

Pan, W. J., Wang, X., Deng, Y. R., Li, J. H., Chen, W., Chiang, J. Y., Yang, J. B., and Zheng, L. 2015. Nondestructive and intuitive determination of circadian chlorophyll rhythms in soybean leaves using multispectral imaging. Sci. Rep. 5:Article 11108. doi:10.1038/srep11108

Robatzek, S., and Somssich, I. E. 2001. A new member of the Arabidopsis WRKY transcription factor family, AtWRKY6, is associated with both senesce- and defence-related processes. Plant J. 28:123-133.

Robatzek, S., and Somssich, I. E. 2002. Targets of AtWRKY6 regulation during plant senescence and pathogen defense. Genes Dev. 16:1139-1149.

Röpenack, E., Parr, A., and Schulze-Lefert, P. 1998. Structural analyses and dynamics of soluble and cell wall-bound phenolics in a broad spectrum resistance to the powdery mildew fungus in barley. J. Biochem. 273:9013-9022.

Savitzky, A., and Golay, J. M. E. 1964. Smoothing and differentiation of data by simplified least squares procedures. Anal. Chem. 36:1627-1639.

Schmelzer, E. 2002. Cell polarization, a crucial process in fungal defence. Trends Plant Sci. 7:411-415.

Scholes, J. D., Lee, P. J., Horton, P., and Lewis, D. H. 1994. Invertase: Understanding changes in the photosynthetic and carbohydrate metabolism of barley leaves infected with powdery mildew. New Phytol. 126:213-222.

Seeholzer, S., Tsuchimatsu, T., Jordan, T., Bieri, S., Pajonk, S., Yang, W., Jahoor, A., Shimizi, K. K., Keller, B., and Schulze-Lefert, P. 2010. Diversity at the Mla powdery mildew resistance locus from cultivated barley reveals sites of positive selection. Mol. Plant-Microbe Interact. 23:497-509. 
Seiffert, U., and Schweizer, P. 2005. A pattern recognition tool for quantitative analysis of in planta hyphal growth of powdery mildew fungi. Mol. PlantMicrobe Interact. 18:906-912.

Shen, Q. H., Zhou, F., Bieri, S., Haizel, T., Shirasu, K., and Schulze-Lefert, P. 2003. Recognition specificity and RAR1/SGT1 dependence in barley Mla disease resistance genes to the powdery mildew fungus. Plant Cell 15:732-744.

Simko, I., Jimenez-Berni, J. A., and Sirault, X. R. R. 2017. Phenomic approaches and tools for phytopathologists. Phytopathology 107:6-17.

Skou, J. P. 1985. On the enhanced callose deposition in barley with mlo powdery mildew resistance genes. Phytopathol. Z. 112:207-216.

Swarbrick, P., Schulze-Lefert, P., and Scholes, J. 2006. Metabolic consequences of susceptible and resistance (race-specific and broad-spectrum) in barley leaves challenged with powdery mildew. Plant Cell Environ. 29:1061-1076.

Thomas, S., Wahabzada, M., Kuska, M. T., Rascher, U., and Mahlein, A. K. 2017. Observation of plant-pathogen interaction by simultaneous hyperspectral imaging reflection and transmission measurements. Funct. Plant Biol. 44:23-34.

Thordal-Christensen, H., Zhang, Z., Wei, Y., and Collinge, D. B. 1997. Subcellular localization of $\mathrm{H}_{2} \mathrm{O}_{2}$ in plants. $\mathrm{H}_{2} \mathrm{O}_{2}$ accumulation in papillae and hypersensitive response during the barley-powdery mildew interaction. Plant J. 11:1187-1194.

Thurau, C., Kersting, K., Wahabzada, M., and Bauckhage, C. 2012. Descriptive matrix factorization for sustainability: Adopting the principle of opposites. Data Min. Knowl. Discovery 24:325-354.

Van Aken, O., and Breusegem, F. 2015. Licensed to kill: Mitochondria, chloroplasts, and cell death. Trends Plant Sci. 20:754-766.
Wahabzada, M., Mahlein, A. K., Bauckhage, C., Steiner, U., Oerke, E. C., and Kersting, K. 2015a. Metro maps of plant disease dynamics-Automated mining of differences using hyperspectral images. PLoS One 10:e0116902.

Wahabzada, M., Mahlein, A. K., Bauckhage, C., Steiner, U., Oerke, E. C., and Kersting, K. 2016. Plant phenotyping using probabilistic topic models: Uncovering the hyperspectral language of plants. Sci. Rep. 6: Article 22482. doi: $10.1038 /$ srep22482

Wahabzada, M., Paulus, S., Kersting, K., and Mahlein, A. K. 2015b. Automated interpretation of 3D laserscanned point clouds for plant organ segmentation. BMC Bioinf. 16:248.

Weßling, R., and Panstruga, R. 2012. Rapid quantification of plant-powdery mildew interactions by qPCR and conidiospore counts. Plant Methods 8:35.

Wolf, G., and Fric, F. 1981. A rapid staining method for Erysiphe graminis f. sp. hordei in and whole barley leaves with a protein-specific dye. Phytopathology 71:596-598.

Yendrek, C. R., Tomaz, T., Montes, C. M., Cao, Y., Morse, A. M., Brown, P. J., McIntyre, L. M., Leakey, A. D. B., and Ainsworth, E. A. 2017. Highthroughput phenotyping of maize leaf physiological and biochemical traits using hyperspectral reflectance. Plant Physiol. 173:614-626.

Zhao, Y. R., Li, X., Yu, K. Q., Cheng, F., and He, Y. 2016. Hyperspectral imaging for determining pigment contents in cucumber leaves in response to angular leaf spot disease. Sci. Rep. 6: Article 27790. doi:10.1038/srep27790

Zhou, F., Kurth, J., Wei, F., Elliott, C., Valé, G., Yahiaoui, N., Keller, B., Somerville, S., Wise, R., and Schulze-Lefert, P. 2001. Cell-autonomous expression of barley Mlal confers race-specific resistance to the powdery mildew fungus via a Rarl-Independent signalling pathway. Plant Cell 13:337-350. 